\title{
Anti c-KIT Antibody-drug Conjugate LOP628
}

National Cancer Institute

\section{Source}

National Cancer Institute. Anti c-KIT Antibody-drug Conjugate LOP628. NCI Thesaurus.

Code $C 117735$

An antibody-drug conjug ate (ADC) consisting of a humanized monoclonal antibody against the stem cell factor receptor c-Kit (SCFR) and conjugated, via a non-cleavable linker, to the cytotoxic agent maytansine, with potential antineoplastic activity. The monoclonal antibody moiety of anti c-KIT ADC LOP628 targets and binds to the cell surface antigen c-Kit. After antibody-antigen interaction followed by internalization, the maytansine moiety binds to tubulin, inhibits microtubule assembly, and induces microtubule disassembly. This leads to a disruption of mitosis and the inhibition of cell proliferation in cancer cells expressing c-Kit. c-Kit, a transmembrane protein and receptor tyrosine kinase, is overexpressed in solid tumors and hematological malignancies; it plays a key role in the regulation of cell differentiation and proliferation. 